IRA-International Journal of Applied Sciences ISSN 2455-4499; Vol.10, Issue 02 (February 2018)

Pg. no. 7-17.

Institute of Research Advances

https://research-advances.org/index.php/IRAJAS

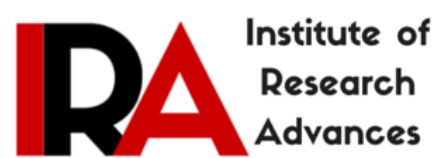

\title{
Antioxidant and Antibacterial Activity of Methanol Extract of Momordica Balsamina
}

\author{
Sajini Souda $^{1 \#}$, Saramma George ${ }^{2}$, Naledi Mannathoko ${ }^{2}$, Irene Goercke ${ }^{3}$, Kelvin Chabaesele ${ }^{4}$ \\ ${ }^{1}$ Department of Pathology, Faculty of Medicine, University of Botswana, Gaborone, Botswana. \\ ${ }^{2}$ Department of Biomedical Sciences, Faculty of Medicine, University of Botswana, Gaborone, Botswana. \\ ${ }^{3}$ School of Allied Health Professions, University of Botswana, Gaborone, Botswana. \\ ${ }^{4}$ Department of Biological Sciences, Faculty of Sciences, University of Botswana, Gaborone, Botswana.
}

\#corresponding author.

Type of Review: Peer Reviewed.

DOI: http://dx.doi.org/10.21013/jas.v10.n2.p1

How to cite this paper:
Souda, S., George, S., Mannathoko, N., Goercke, I., Chabaesele, K. (2018). Antioxidant and Antibacterial
Activity of Methanol Extract of Momordica Balsamina. IRA International Journal of Applied Sciences (ISSN 2455-
4499), 10(2), 7-17. doi:http://dx.doi.org/10.21013/jas.v10.n2.p1

(C) Institute of Research Advances.

\section{(c) BY-NC}

This work is licensed under a Creative Commons Attribution-Non Commercial 4.0 International License subject to proper citation to the publication source of the work.

Disclaimer: The scholarly papers as reviewed and published by the Institute of Research Advances (IRA) are the views and opinions of their respective authors and are not the views or opinions of the IRA. The IRA disclaims of any harm or loss caused due to the published content to any party.

Institute of Research Advances is an institutional publisher member of Publishers Inter Linking Association Inc. (PILA-CrossRef), USA. The institute is an institutional signatory to the Budapest Open Access Initiative, Hungary advocating the open access of scientific and scholarly knowledge. The Institute is a registered content provider under Open Access Initiative Protocol for Metadata Harvesting (OAI-PMH).

The journal is indexed \& included in CAS Source Index of Chemical Abstracts Service of American Chemical Society (USA), WorldCat Discovery Service (USA), CrossRef Metadata Search (USA), WorldCat (USA), OCLC (USA), Open J-Gate (India), EZB (Germany) Scilit (Switzerland), Airiti (China), Bielefeld Academic Search Engine (BASE) of Bielefeld University, Germany, PKP Index of Simon Fraser University, Canada. 


\begin{abstract}
Momordica balsamina is considered as a miracle herb used in African traditional medicine due to its tremendous medicinal and nutritional properties. In this present study we evaluated the antioxidant and antimicrobial activities of the methanol extract of Momordica balsamina (MEMB). Phytochemical screening followed by thin layer chromatography and spectrophotometrydone to measure the radical scavenging activity of 2,2-diphenyl-1-picrylhydrazyl (DPPH). Total phenolic content and total antioxidant activity of MEMB was determined. Zones of inhibition, minimum inhibitory (MIC) and minimum bactericidal concentrations (MBC) were measured by agar diffusion and liquid broth dilution assays to assess the antimicrobial activities of MEMB. Phytochemicals isolated were flavonoids, tannins, coumarins, terpenoids and phenols. The antioxidant potential and antimicrobial activity of MEMB can be attributed to the total phenolic content and other bioactive phytochemicals.MEMB showed antimicrobicidal activity more against Gram positive than Gram negative organisms. S.agalactiae,S.aureus (ATCC 25923) and L.monocytogenes were more susceptible than Proteus mirabilis, E.coli, K.pneumoniae, P.aeruginosa or S. typhimurium. MEMB also showed antifungal activity against C.albicans species though at a higher concentration[MIC $-0.938 \mathrm{mg} / \mathrm{ml}$ and $\mathrm{MBC}-1.875 \mathrm{mg} / \mathrm{ml}$. MEMB can therefore be considered as a potential medication in the management of infectious diseases.
\end{abstract}

Key words: Methanol extract of Momordica balsamina, phytochemicals, antioxidants, total phenolic content, antimicrobial activity, Botswana.

\title{
1.0 Introduction
}

Momordica balsamina (aka Balsam apple, bitter cucumber or bitter melon, African pumpkin)is a miracle herb which has tremendous medicinal and nutritional properties(Kaur et al., 2012).It is a high-climbing vine from family Cucurbitaceae, fairly common and widespread in Namibia, Botswana, Swaziland and all the provinces of South Africa except the Western Cape. It is also indigenous to tropical Africa, Asia, Arabia, India and Australia(Singh Thakur et al., 2009; Ramalhete et al., 2011; Thakur et al., 2011).

The leaves of Momordica balsamina are an important source of nutrients including 17 amino acids, various minerals like potassium, magnesium, phosphorus, calcium, sodium, zinc, manganese, iron and vitamins A and C. Its high potassium content is a good source for the management of hypertension and other cardiovascular conditions (Karumi.Y, Onyeyili PA, 2004; Flyman and Afolayan, 2007; Singh Thakur et al., 2009).

Momordica plants also contain biologically active phytochemicals, such as resins, alkaloids, flavonoids, anthraquinone, steroids, glycosides, terpenes, saponins and carbohydrate(Singh Thakur et al., 2009). Flavonoids and phenolic compounds are considered as antioxidants due to their free radical scavenging activity and lipid peroxidation inhibition activity. Phenolic compounds are involved in conferring plants with oxidative stress tolerance and flavonoids suppress reactive oxygen formation, chelate trace elements involved in free-radical production, scavenge reactive species, and up-regulate and protect antioxidant defense(Baba and Malik, 2014).Antioxidants are capable of stabilizing, or deactivating free radicals before the latter attack cells and biological targets, The antioxidant potential of a plant is assessed by determining the total phenolic content and generation of the ABTS radical action(Akula and Odhav, 2008). M. balsamina has also been reported to be a potent inhibitor of HIV-1 replication in vitro. due to the presence of ribosome inactivating proteins, Momordin I and II, by significantly increasing the CD4 count within two weeks (Singh Thakur et al., 2009).

Various studies have reported that the extract of the M. balsamina plant has antiviral, anti-inflammatory, antidiarrheal, antiseptic, antimicrobial, antidiabetic and anti-plasmodial activity and is being used in African traditional medicine(Benoit-Vical et al., 2006; Ramalhete et al., 2011; Singh Thakur et al., 2009).

This present study evaluated the phytochemicals, antioxidant potential, total phenolic content, and antimicrobial activities of the methanol extract of Momordica balsamina (MEMB). 


\subsection{Materials and Methods}

\subsection{Collection and identification of plants}

Identification of the aerial parts of Momordica Balsamina, collected locally from Botswana was done at the University of Botswana Herbarium by Dr. M. P. Setshogo. The voucher number for the submitted specimen was (G2016/, A02).

\subsection{Preparation of the methanol extract}

Methanol extract of M.balsamina was obtained from the plant parts as detailed elsewhere using $70 \%$ methanol and Buchi type rotary vacuum evaporator (Souda et al., 2016).

\subsection{Chemicals}

All the chemicals, solvents and reagents like DPPH (2,2-diphenyl-l-picrylhydrazyl), Folin-Ciocalteau reagent, gallic acid (AR),ascorbic acid and anhydrous sodium carbonate used were analytical grade and bought from SigmaAldrich Chemical Company, (St. Louis, MO) USA., Fluka Chemicals (Steinheim, Germany), Rochelle Chemicals (South Africa). Unilab (South Africa). The silica gel coated aluminium backed TLC sheets were ready made (Souda et al., 2016; Mannathoko et al., 2017).

\subsection{Phytochemical screening}

The screening tests were performed in duplicates as detailed by Mazimba (2015), for flavonoids, tannins, saponins, coumarins terpenoids, fatty acids, phenols, aminoacids, alpha proteins, quinones, oxalates(Mazimba et al., 2015; Souda et al., 2016).

\subsection{Antioxidant Status}

The methods used to determine the free radical scavenging effects and in turn the antioxidant property were the TLC - Semi Quantitative DPPH Assay described by Juma and Majinda, (2004), the spectrophotometric method using DPPH, modified by Yeboah and Majinda, (2009), the total phenolic content by method described by Yeboah and Majinda (2009) and ABTS radical scavenging activity described in detail by Pellegriniet al.,(1999)(Saramma and Padmaja, 2013; Souda et al., 2016; Mannathoko et al., 2017).

\subsection{Antimicrobial activity}

\subsubsection{Microbial cultures}

The antimicrobial activity of MEMB was tested using ATCC strains and a clinical isolate obtained from the Department of Microbiology, School of Allied Health Professions, University of Botswana, Botswana. The microorganisms included Gram positive cocci : Staphylococcusaureus(ATCC 25923), Methicillin resistant Staphylococcus aureus (ATCC 43300), Staphylococcus aureus from a patient sample, Staphylococcus epidermidis(ATCC12228) and Streptococcus agalactiae (ATCC 27956), Gram positive bacilli: Listeria monocytogenes, Gram negative bacilli: Escherichia coli (ATCC10536), Klebsiella pneumoniae(ATCC700603), Proteus mirabilis(ATCC 25933), Pseudomonas aeruginosa(ATCC 27853), Salmonella typhimurium(ATCC 14028) and $a$ fungus: Candida albicans(ATCC 90028). All organisms were tested for purity and maintained in nutrient agar plates (OXOID).

\subsubsection{Antimicrobial susceptibility testing}

Antimicrobial susceptibility testing to the different microorganisms were carried out by well diffusion on Mueller Hinton agar plates (MHA) (MAST) with some modification(Marie B. Coyle, 2005)and also reported elsewhere(Souda et al., 2016; Mannathoko et al., 2017).In brief, $6 \mathrm{~mm}$ diameter wells were made in the MHA agar plate with the base of a sterilized glass Pasteur pipette. Lawn cultures of each of the bacterial suspensions in Tryptone Soya broth (OXOID), adjusted to $0.5 \mathrm{McFarland}$ standard turbidity, (equivalent to a bacterial suspension of $1.5 \times 10^{8}$ colony forming units per $\mathrm{ml}(\mathrm{CFU} / \mathrm{ml})$ ), were made on the MHA plates. 100 microliters $(\mu \mathrm{l})$ of MEMB, dissolved in $10 \%$ dimethyl sulfoxide (DMSO), which gives a concentration of $20 \mathrm{mg}$, was added to each well. DMSO $(100 \mu \mathrm{l})$ was also added to the wells in each plate as the control. The tests were done in duplicates.

Ampicillin $(10 \mu \mathrm{g})$ (Mast Diagnostics) discs were used as the positive control for each of the organism, meropenem $(10 \mu \mathrm{g})$ for Staphylococcus aureus(ATCC 43300), ceftazidime (30 $\mathrm{g}$ ) for Pseudomonas aeruginosa, co-trimoxazole (CTX $25 \mu \mathrm{g})$ for Klebsiella pneumonia and fluconazole $(25 \mu \mathrm{g})$ for C.albicans. $20 \mu 1$ of DMSO was used as the negative control. 
The plates were incubated at $37^{\circ} \mathrm{C}$ in an incubator for 24 hours and zones of inhibition measured using Vernier calipers.

\subsubsection{Minimum Inhibitory Concentration}

Micro well dilution method with some modifications (Marie B. Coyle, 2005) was done to determine the minimal inhibitory concentration (MIC) of the extract for each of the microorganisms using 96 well plates (Souda et al., 2016; Mannathoko et al., 2017).

The lowest concentration of the sample that prevented visible growth after 24 hours incubation at $37^{\circ} \mathrm{C}$, indicated by turbidity, was considered as the MIC of the extract.

The minimum bactericidal concentrations (MBC) were also determined by subculturing the suspension from all the wells on to a MHA plate and incubated at $37^{\circ} \mathrm{C}$ in ambient air for 24 hours. The MBC was defined as the lowest concentration of the compounds to inhibit the growth of microorganisms(Nakamura et al., 1999). The tests were done in duplicate.

The dilution assays are more reliable than diffusion assays due to many factors (Rios, Recio and Villar, 1988) The MBC values are more reliable than the MIC values which depends only on the visual observation of turbidity (Junaid et al.2006). MIC values $<1 \mathrm{mg} / \mathrm{mL}$ expressed by crude plant extracts are regarded as indicators of good antimicrobial activity with potential physiological relevance in vivo(Mann, 2012)

\subsection{Statistical analysis}

All data were expressed as the mean \pm S.E and standard deviation.

\section{Results}

\subsection{Phytochemical screening of MEMB.}

Table 1: Phytochemical screening of MEMB

\begin{tabular}{|l|l|}
\hline Test & MEMB \\
\hline Flavonoids & + \\
\hline Tannins & + \\
\hline Saponins & - \\
\hline Coumarins & + \\
\hline Terpenoids & + \\
\hline Fatty acids & - \\
\hline Phenols & + \\
\hline Amino acids & - \\
\hline$\alpha$ proteins & - \\
\hline Quinones & - \\
\hline Oxalate & - \\
\hline
\end{tabular}

\subsection{Antioxidant Assay status}

\subsubsection{TLC - Semi Quantitative DPPH}

In the presence of an antioxidant molecule, the free radical, DPPH in the MEMB is reduced, giving rise to a colorless methanol solution. The decrease in the concentration of DPPH radical due to antioxidant activity of the MEMB and the standards used, gallic acid and ascorbic acid is shown in Fig 1. 


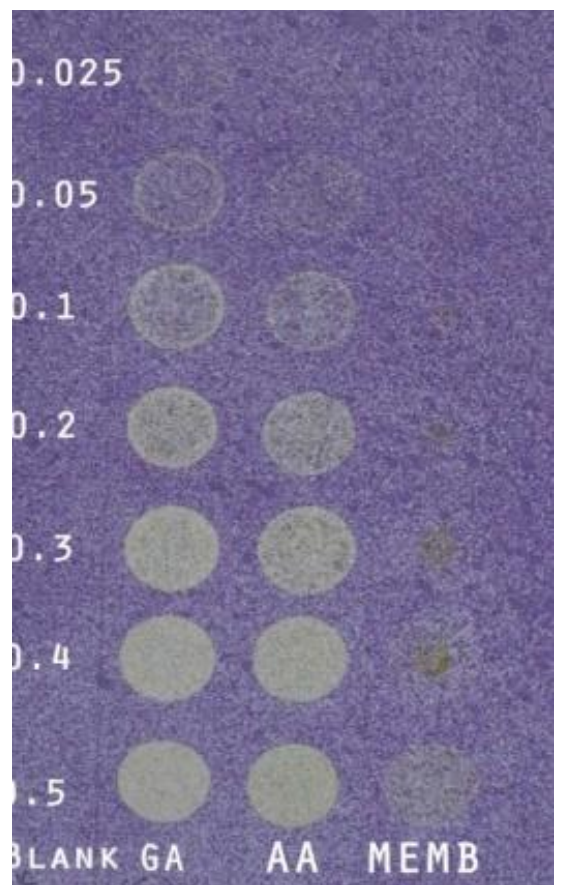

Fig 1: TLC- Semi quantitative DPPH activity of MEMB.

\subsubsection{DPPH Spectrophotometric method}

The free radical scavenging activity of M.balsamina is determined from the reduction in absorbance at $517 \mathrm{~nm}$ and compared with the standard gallic acid and ascorbic acid, as shown in Fig 2 using the formula DPPH Inhibition \%= Absorbance control- Absorbance sample)/Absorbance control x 100.

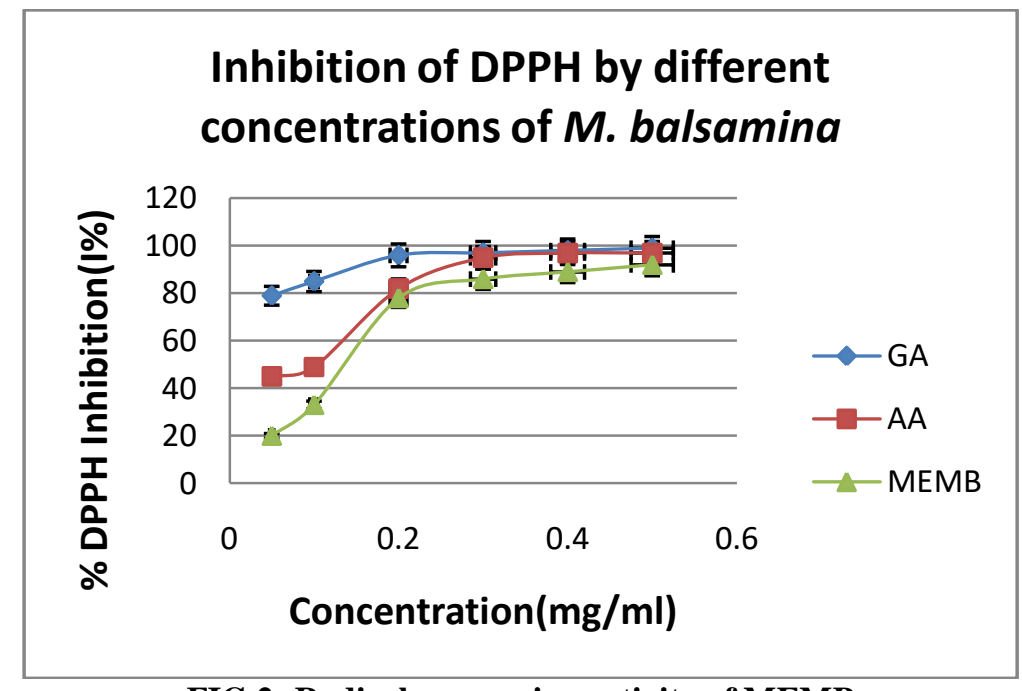

FIG 2: Radical scavenging activity of MEMB

(GA- Gallic acid, AA -Ascorbic acid, methanol extract of M.balsamina- MEMB)

\subsubsection{Total phenolic content:}

TPC of the MEMB was calculated from the linear regression equation of the standard curve $y=36.84 x+0.1069$ using the equation $(\mathrm{X}=(\mathrm{Y}-0.064) / 0.094 \mathrm{X} 100)$ (Souda et al., 2016).From this equation the equivalent concentration of gallic acid $254.21 \pm 0.43 \mathrm{mg} / \mathrm{mL}$ was determined for each extract and converted to $\mathrm{mg}$ of gallic acid equivalents/g of dry extract (mg GAE/g). 
Table 2: Total Phenolic content

\begin{tabular}{|l|l|}
\hline $\begin{array}{l}\text { Concentration } \\
(\mathrm{mg} / \mathrm{ml})\end{array}$ & $\begin{array}{l}\text { TPC (mg GAE/100g) } \\
\text { Momordica }\end{array}$ \\
\hline 0.1 & 9.84 \\
\hline 0.2 & 17.02 \\
\hline 0.3 & 26.24 \\
\hline 0.4 & 38.3 \\
\hline 0.5 & 49.29 \\
\hline
\end{tabular}

\subsubsection{ABTS radical scavenging activity}

The method is a decolorisation assay carried out by adding DMSO diluted solution containing ABTS and potassium persulphate to different concentration of the MEMB and absorbance read at $734 \mathrm{~nm}$ along with the reference standard gallic acid and ascorbic acid and percentage inhibition calculated.

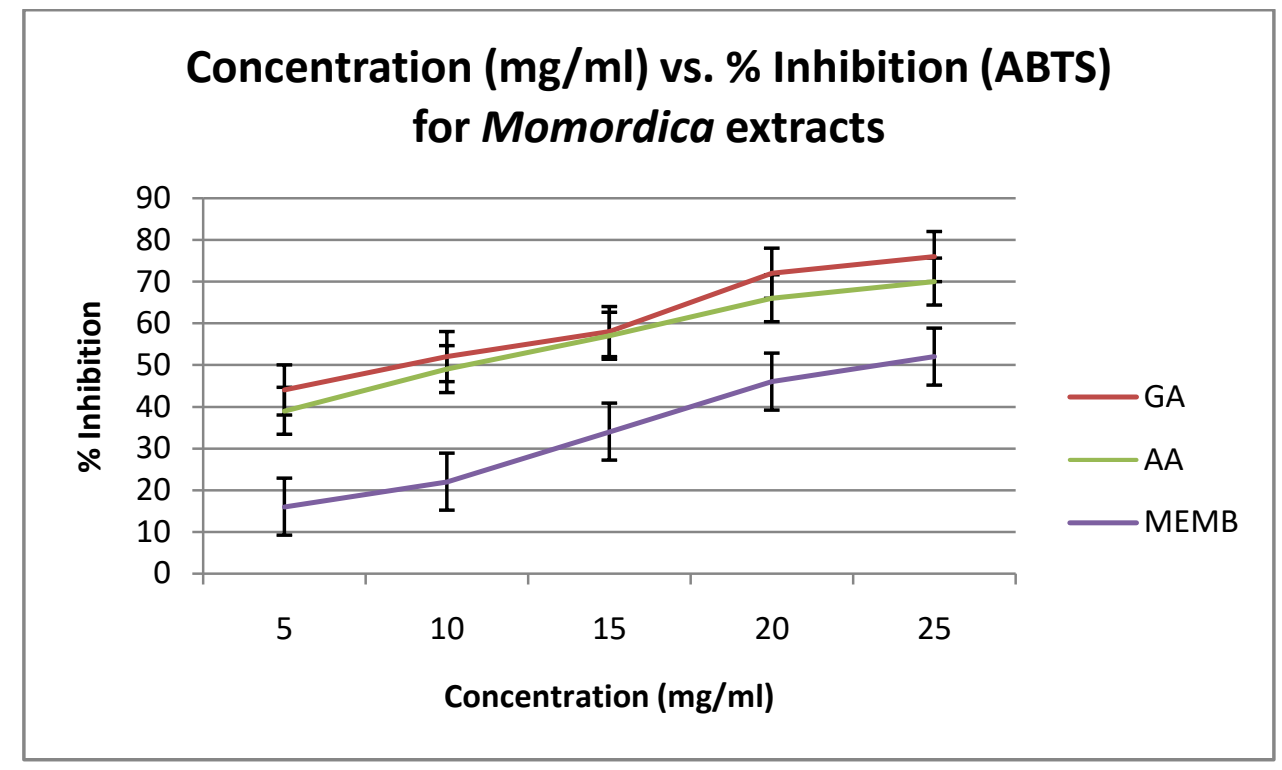

Fig 3: ABTS radical scavenging activity

(GA- Gallic acid, AA -Ascorbic acid, MEMB- Methanol extract of Momordica balsamina)

\subsection{Antimicrobial activity}

The activity of MEMB against the different microorganisms was examined and their antimicrobial activity was determined by the presence or absence of inhibition zones around the well, zone diameter (Table 3), MIC values and MBC values (Table 4).

MEMB showed variable antimicrobial activity against all the microorganisms tested using well diffusion method. Considerable anti-microbial activity was noted against the Gram positive cocci Streptococcus agalactiae(18mm) and Gram negative bacilli Proteus mirabilis $(20 \mathrm{~mm})$, although not comparable to the controls. The diameters of the zone of inhibition for all the other microorganisms were $\leq 15 \mathrm{~mm}$. 
Table 3: Antimicrobial activity of MEMB by the well-diffusion method.

\begin{tabular}{|c|c|c|}
\hline Organisms & $\begin{array}{c}\text { Well diffusion } \\
(100 \mu \mathrm{l}=20 \mathrm{mg} / \mathrm{ml} \\
\text { Zone of inhibition } \\
(\mathrm{mm})\end{array}$ & $\begin{array}{c}\text { Control } \\
\text { (Ampicillin } 10 \mu \mathrm{g}) \\
\text { Zoneof inhibition }(\mathrm{mm})\end{array}$ \\
\hline \multicolumn{3}{|l|}{ Gram positive Organisms } \\
\hline $\begin{array}{l}\text { Staphylococcus aureus } \\
\text { (ATCC 25923) }\end{array}$ & 14 & 33 \\
\hline $\begin{array}{l}\text { Staphylococcus aureus } \\
\text { (Methicillin resistant) } \\
\text { (ATCC 43300) }\end{array}$ & 11 & $29^{\mathrm{a}}$ \\
\hline $\begin{array}{l}\text { Staphylococcus aureus. } \\
\text { (patient sample) }\end{array}$ & 15 & 26 \\
\hline $\begin{array}{l}\text { Staphylococcus epidermidis } \\
\text { (ATCC 12228) }\end{array}$ & 15 & 28 \\
\hline $\begin{array}{l}\text { Streptococcus agalactiae } \\
\text { (ATCC 27956) }\end{array}$ & 18 & 34 \\
\hline Listeria monocytogenes & 12 & 37 \\
\hline \multicolumn{3}{|l|}{ Gram negative Organisms } \\
\hline $\begin{array}{l}\text { Escherichia coli } \\
\text { (ATCC 10536) }\end{array}$ & $12.5 \pm 0.5$ & 19 \\
\hline $\begin{array}{l}\text { Klebsiella pneumoniae } \\
\text { (ATCC 700603) }\end{array}$ & 10 & $23^{b}$ \\
\hline $\begin{array}{l}\text { Proteus mirabilis } \\
\text { (ATCC 12228) }\end{array}$ & 20 & 30 \\
\hline $\begin{array}{l}\text { Pseudomonas aeruginosa } \\
\text { (ATCC 27853) }\end{array}$ & 13 & $27^{\mathrm{c}}$ \\
\hline $\begin{array}{l}\text { Salmonella typhimurium } \\
\text { (ATCC 14028) }\end{array}$ & $13.5 \pm 0.5$ & 24 \\
\hline \multicolumn{3}{|l|}{ Fungus } \\
\hline $\begin{array}{l}\text { Candida albicans } \\
\text { (ATCC 90028) }\end{array}$ & $15 \pm 1$ & $25^{\mathrm{d}}$ \\
\hline
\end{tabular}

${ }^{a}$ Meropenam (10ug), ${ }^{b}$ CTX (25ug) ${ }^{c}$ Ceftazidime (30ug), ${ }^{d}$ Fluconazole (25ug).

Table 4: Antimicrobial activity of MEMB by micro dilution assay, (MIC and MBC).

\begin{tabular}{|l|c|c|}
\hline Organisms & $\begin{array}{c}\text { MIC } \\
(\mathrm{mg} / \mathrm{ml})\end{array}$ & $\begin{array}{c}\text { MBC } \\
(\mathrm{mg} / \mathrm{ml})\end{array}$ \\
\hline Gram positive Organisms & & 0.938 \\
\hline $\begin{array}{l}\text { Staphylococcus aureus } \\
\text { (ATCC 25923) }\end{array}$ & 0.234 & \\
\hline $\begin{array}{l}\text { Staphylococcus aureus } \\
\text { (Methicillin resistant) } \\
\text { (ATCC 43300) }\end{array}$ & 0.469 & 1.875 \\
\hline $\begin{array}{l}\text { Staphylococcus aureus. } \\
\text { (patient sample) }\end{array}$ & 0.938 & 1.875 \\
\hline $\begin{array}{l}\text { Staphylococcus epidermidis } \\
\text { (ATCC 12228) }\end{array}$ & 0.938 & 1.875 \\
\hline $\begin{array}{l}\text { Streptococcus agalactiae } \\
\text { (ATCC 27956) }\end{array}$ & 0.234 & 0.234 \\
\hline
\end{tabular}




\begin{tabular}{|l|c|c|}
\hline Listeria monocytogenes & 0.234 & 0.469 \\
\hline Gram negative Organisms & & \\
\hline $\begin{array}{l}\text { Escherichia coli } \\
\text { (ATCC 10536) }\end{array}$ & 1.875 & 1.875 \\
\hline $\begin{array}{l}\text { Klebsiella pneumoniae } \\
\text { (ATCC 700603) }\end{array}$ & 0.469 & 1.875 \\
\hline $\begin{array}{l}\text { Proteus mirabilis } \\
\text { (ATCC 12228) }\end{array}$ & 0.234 & 0.938 \\
\hline $\begin{array}{l}\text { Pseudomonas aeruginosa } \\
\text { (ATCC 27853) }\end{array}$ & 0.234 & 1.875 \\
\hline $\begin{array}{l}\text { Salmonella typhimurium } \\
\text { (ATCC 14028) }\end{array}$ & 0.469 & 0.938 \\
\hline Fungus & & \\
\hline $\begin{array}{l}\text { Candida albicans } \\
\text { (ATCC 90028) }\end{array}$ & 0.938 & 1.875 \\
\hline
\end{tabular}

The range of MIC for Gram positive and Gram negative organisms was between $0.234-0.938 \mathrm{mg} / \mathrm{mL}$ and $0.234-$ $1.875 \mathrm{mg} / \mathrm{mL}$ respectively. The MEMB had an MIC of $<1 \mathrm{mg} / \mathrm{mL}$ against all organisms tested in this study, except E.coli.

The range of MBC for the Gram positive bacteria was from $0.234 \mathrm{mg} / \mathrm{mL}-1.875 \mathrm{mg} / \mathrm{ml}$ and for Gram negative bacteria from $0.938 \mathrm{mg} / \mathrm{mL}-1.875 \mathrm{mg} / \mathrm{mL}$. The Gram positive bacteria Streptococcus agalactiae, Listeria monocytogenes, Staphylococcus aureus (ATCC 25923) and the Gram negative organisms, Proteus mirabilis has an $\mathrm{MBC}$ of $<1 \mathrm{mg} / \mathrm{mL}$ indicating good antimicrobial activity of MEMB.

Antifungal activity of MEMB was shown by its activity against Candida albicans, with MIC of $0.938 \mathrm{mg} / \mathrm{ml}$, MBC of $1.875 \mathrm{mg} / \mathrm{ml}$ and zone of inhibition of $15 \mathrm{~mm}$.

The solvents used for the dilutions were also tested for antimicrobial activity and was found to have no inhibitory activity.

\section{Discussion}

\section{Phytochemicals:}

In our study, the phytochemicals isolated were flavonoids, tannins, coumarins, terpenoids and phenols similar to other reported studies(Singh Thakur et al., 2009). Saponin was absent in our extract(Karumi.Y, Onyeyili PA, 2004). The uncontrolled production of oxygen free radicals and the unbalanced mechanism of antioxidant protection result in the onset of many diseases. The antioxidants when present at low concentrations compared to that of an oxidizable substrate, significantly delay or inhibit the oxidation of that substrate(Akula and Odhav, 2008). Free radical and hydroxyl free radical-scavengers prevent damage to cellular components arising as a consequence of chemical reactions and are critical for maintaining optimal cellular and systemic health and wellbeing (Singh Thakur et al., 2009).Most antioxidants isolated from higher plants are phenolic compounds having carbon-based aromatic phenyl-ring compounds which are easily oxidized to quinones by reactive oxygen species, a property that helps to account for their free radical scavenging capacity. The antioxidant activity of phenolics is mainly due to their redox properties, which allow them to act as reducing agents, hydrogen donors, and singlet oxygen quenchers. Phenolic compounds also have a metal chelation property and lipoxygenase inhibitory properties that have been used for the treatment of inflammatory diseases. (Akula and Odhav, 2008).

In the radical scavenging studies using DPPH, MEMB almost completely inhibited DPPH absorption (92\%).Similar result was reported along with significant inhibition of 5-lipoxygenase (5-Lox) activity by Singh Thakur, (2009). 


\section{Antimicrobial activity:}

The methanol extract of M.balsamina, in this study also, showed antimicrobicidal activity more against Gram positive than Gram negative organisms, as indicated by the MIC and MBC which is similar to reports from other studies(Singh Thakur et al., 2009; Ajji, Walder and Puri, 2016)

The phytochemicals present in the plant extracts like phenols, flavonoids and tannins have been reported to complex with proteins and polysaccharides leading to inactivation of microbial adhesion enzymes, cell envelope, and the transport protein accounting for its antimicrobial activity(Singh Thakur et al., 2009).

Gram positive organisms have been reported to be more susceptible to phenols which are the predominant active chemical compounds in the plant extracts. The phenolic component can cause leakage of intracellular ATP and potassium ions leading to bacterial cell death. The difference in the susceptibility of Gram positive and Gram negative bacteria to the extract of M.balsamina is probably because of the difference in the outer membrane structure of the Gram positive and Gram negative bacterial cell wall as reported also by other studies(Obinna et al., 2009; Joshi, 2013).Gram-positive bacteria contain an outer peptidoglycan layer, which is an ineffective permeability barrier(Baba and Malik, 2014).Gram negative bacteria have a hydrophilic outer membrane which blocks penetration of hydrophobic compounds into the cell membranes(Mannathoko et al., 2017). The flavonoids complexes with bacterial cell wall and disrupt the membrane integrity. It has also been shown that flavonoids interfere with various bacterialvirulence factors, including enzymes, toxins and signal receptors(Cushnie and Lamb, 2005). Tannins have been reported to inhibit microbial adhesion enzymes and cell envelope proteins. Tannins also have been shown to have antiviral activity by inhibiting viral reverse transcriptase (Mann, 2012).

Another active component found in the MEMB, is a ribosome inhibiting protein (RIPs) called balsamin, a class of defense proteins reported to have a DNase like, antibacterial activity against $S$. aureus, S. epidermidis, S.enterica, E. faecalis, E. coli and P. aeruginosa (Kaur et al., 2012; Ajji, Walder and Puri, 2016).

Cucurbitane-type triterpenoids compounds, isolated from $M$. balsamina also have been shown to inhibit the efflux pump system of Gram-positive bacteria. They are ineffective against the efflux pump systems of Gram negative bacterial strains like S.typhimurium and E. coli strains This may be due to the difference in the outer membrane and its lipopolysaccharide layer that can act as an effective barrier to these compounds or to RND-type efflux pumps that are not affected by the compounds studied (Ramalhete et al., 2011).

In this study, we found that among the Gram positive bacteria studied, S.agalactiae was more susceptible to the antimicrobial effect of the extract. An almost equal susceptibility was noticed for S.aureus(ATCC 25923) andL.monocytogenes. Among Gram negative organisms, P. mirabilis was more susceptible than E.coli, K.pneumoniae, P.aeruginosa orS. typhimurium.

The methanol extract of M.balsamina also showed antifungal activity against C.albicans species though at a higher concentration [MIC $-0.938 \mathrm{mg} / \mathrm{ml}$ and MBC- $1.875 \mathrm{mg} / \mathrm{ml}$ ]. Momordica plants produce a number of proteins and peptides that are indicative of antifungal activity, including trypsin inhibitors, lectins, ribosome-inactivating proteins and ribonucleases (Burger et al., 2010).

\section{Conclusions}

The phytochemicals and proteins like RIP's, balsamin, peptide and lectins found in the extracts of M.balsamina plant are shown to have antioxidant, antimicrobial, antifungal and antiviral properties. These substances contribute to its medicinal value and rationalize the use of the plant extract as traditional medicines in the treatment of infections due to bacteria, fungus, and viruses. They can also be valuable in the management of non- communicable diseases like diabetes, hypertension and cancer. Studies on the preparation, effective doses and side effects of these extracts are warranted. 


\section{Acknowledgment}

Authors are thankful to the Office of Research and Development of the University of Botswana for providing funds to carry out this study. We are also thankful to the School of Allied Health Professions, Faculty of Health Sciences, University of Botswana, for permission to conduct the study in the lab.

Consent: Not applicable.

Ethical Approval: Not applicable.

\section{References:}

[1] Ajji, P. K., Walder, K. and Puri, M. (2016) 'Functional Analysis of a Type-I Ribosome Inactivating Protein Balsamin from Momordica balsamina with Anti-Microbial and DNase Activity', Plant Foods for Human Nutrition. Plant Foods for Human Nutrition, 71(3), pp. 265-271. doi: 10.1007/s11130-016-0555-4.

[2] Akula, U. S. and Odhav, B. (2008) 'In vitro 5-Lipoxygenase inhibition of polyphenolic antioxidants from undomesticated plants of South Africa', Journal of Medicinal Plants Research, 2(9), pp. 207-212. Available at: http://www.academicjournals.org/JMPR.

[3] Baba, S. A. and Malik, S. A. (2014) 'Evaluation of antioxidant and antibacterial activity of methanolic extracts of Gentiana kurroo royle', Saudi Journal of Biological Sciences. King Saud University, 21(5), pp. 493-498. doi: 10.1016/j.sjbs.2014.06.004.

[4] Benoit-Vical, F. et al. (2006) 'In vitro and in vivo antiplasmodial activity of Momordica balsamina alone or in a traditional mixture', Chemotherapy, 52(6), pp. 288-292. doi: 10.1159/000095960.

[5] Burger, Y. et al. (2010) 'Variation in antifungal activity in extracts from Momordica plants', Israel Journal of Plant Sciences, 58(1), pp. 1-7. doi: 10.1560/IJPS.58.1.1.

[6] Cushnie, T. P. T. and Lamb, A. J. (2005) 'Antimicrobial activity of flavonoids', International Journal of Antimicrobial Agents, 26(5), pp. 343-356. doi: 10.1016/j.ijantimicag.2005.09.002.

[7] Flyman, M. V and Afolayan, A. J. (2007) 'Proximate and mineral composition of the leaves of Momordica balsamina L.: an under-utilized wild vegetable in Botswana.', International journal of food sciences and nutrition, 58(November), pp. 419-23. doi: 10.1080/09637480701253417.

[8] George Saramma, Sajini Souda, Vincent Setlare, K. T. and P. C. (2016) 'An Evaluation Of The Antioxidant And AntiDiabetic Effect Of The Methanol Extract Of Hypoxis Hemerocallideacorm (Mehhc) On Stz Induced Sd Rats', International Journal Of Recent Scientific Research, 7(9), Pp. 13393-13402.

[9] Joshi, R. K. (2013) 'Chemical Composition, In Vitro Antimicrobial and Antioxidant Activities of the Essential Oils of Ocimum Gratissimum, O. Sanctum and their Major Constituents.', Indian journal of pharmaceutical sciences, 75(4), pp. 457-62. doi: 10.4103/0250-474X.119834.

[10] Junaid, S. A., Olabode, A. O., Onwuliri, F. C., Okwori, A. E. J. and Agina, S. E. (2006) 'The antimicrobial properties of Ocimum gratissimum extracts on some selected bacterial gastrointestinal isolates', African Journal of Biotechnology, 5(22), pp. 2315-2321. Available at: http://www.academicjournals.org/AJB.

[11] Karumi.Y, Onyeyili PA, O. V. O. (2004) 'Identification of Active Principles of M.balasamina (Balsam Apple) Leaf Extract.', Journal of medical sciences, 4(3), pp. 179-182

[12] Kaur, I. et al. (2012) 'Balsamin, a novel ribosome-inactivating protein from the seeds of Balsam apple Momordica balsamina', Amino Acids, 43(2), pp. 973-981. doi: 10.1007/s00726-011-1162-1.

[13] Mann, A. (2012) 'Phytochemical Constituents and Antimicrobial and Grain Protectant Activities of Clove Basil ( Ocimum gratissimum L .) Grown in Nigeria', International Journal of Plant Research, 2(1), pp. 51-58. doi: 10.5923/j.plant.20120201.08.

[14] Mannathoko, N. et al. (2017) 'An in-vitro Analysis of the Antioxidant and Antimicrobial Properties of the Methanol Extract of Hypoxis hemerocallideacorm ( MEHHC ) from Botswana', 19(6), pp. 1-12. doi: 10.9734/MRJI/2017/32936.

[15] Marie B. Coyle (2005) Manual of Antimicrobial Susceptibility Testing, American Society for Microbiology. doi: 10.1007/s13398-014-0173-7.2.

[16] Mazimba, O. et al. (2015) 'Cinnamomum verum: Ethylacetate and methanol extracts antioxidant and antimicrobial activity', Journal of Medicinal Plants Studies JMPS, 28(33), pp. 28-32.

[17] Nakamura, C. V et al. (1999) 'Antibacterial activity of Ocimum gratissimum L. essential oil.', Memórias do Instituto Oswaldo Cruz, 94(5), pp. 675-8. doi: 10.1590/S0074-02761999000500022.

[18] Obinna, C. et al. (2009) 'Antibacterial effects of extracts of Ocimum gratissimum and piper guineense on Escherichia coli and Staphylococcus aureus', 3(3), pp. 77-81.

[19] Ramalhete, C. et al. (2011) 'Inhibition of efflux pumps in meticillin-resistant Staphylococcus aureus and Enterococcus faecalis resistant strains by triterpenoids from Momordica balsamina', International Journal of Antimicrobial Agents, 37(1), pp. 70-74. doi: 10.1016/j.ijantimicag.2010.09.011.

[20] Rios, J. L., Recio, M. C. and Villar, A. (1988) 'Screening methods for natural products with antimicrobial activity: A review of the literature', Journal of Ethnopharmacology, 23(2-3), pp. 127-149. doi: 10.1016/0378-8741(88)90001-3.

[21] Saramma, G. A. and Padmaja, C. (2013) 'Effects of the methanol extract of Ocimum gratissimum on cumen 
hydroperoxide-induced oxidative stress on rat liver tissue', International Journal of Biological and Chemical Sciences, pp. 33-46.

[22] Singh Thakur, G. et al. (2009) 'Momordica balsamina: A Medicinal and Neutraceutical Plant for Health Care Management', Current Pharmaceutical Biotechnology, 10(September), pp. 667-682. doi: 10.2174/138920109789542066.

[23] Souda, S. et al. (2016) 'An Evaluation of the Antioxidant Status and Antimicrobial Activity of the Methanol Extract of Ocimum Gratissimum', IRA-International Journal of Applied Sciences, 5(1), pp. 40-56.

[24] Thakur, G. S. et al. (2011) 'Factors affecting in vitro propagation of Momordica balsamina: A medicinal and nutritional climber', Physiology and Molecular Biology of Plants, 17(2), pp. 193-197. doi: 10.1007/s12298-011-0052-z. 